\title{
ENERGY EFFICIENCY OF THE MINERAL FERTILIZER APPLICATION IN CROP PRODUCTION
}

\section{ENERGETSKA EFIKASNOST APLIKACIJE MINERALNIH ĐUBRIVA U PROIZVODNJI RATARSKIH KULTURA}

\author{
Aleksandra DIMITRIJEVIĆ, Marija GAVRILOVIĆ \\ Zoran MILEUSNIĆ, Rajko MIODRAGOVIĆ \\ University of Belgrade - Faculty of Agriculture, Nemanjina 6, Belgrade, Serbia \\ email:saskad@agrif.bg.ac.rs
}

\begin{abstract}
The efficiency of primary agricultural production is under constant analysis relative to energy, economy and ecology. Notwithstanding technological innovations in agricultural production, engineers and researchers are still seeking to create a production system that would render the primary agricultural production more energy efficient and ecologically sustainable.

The purpose of this paper is to examine the energy consumption and efficiency of crop production with an emphasis on the importance of mineral fertilizers and their influence on the overall energy consumption. The results obtained indicate that mineral fertilizers claim a share of the total energy consumption in crop production ranging from $40.53 \%$ in sunflowers to $55.19 \%$ in maize. A statistically significant correlation was found between the energy inputs for fertilizers and crop yields. The regression analysis performed showed a positive correlation between the energy inputs for fertilizers and yields in all the crops considered, with the exception of wheat.
\end{abstract}

Key words: mineral fertilizers, crop production, energy consumption, energy efficiency

\section{REZIME}

Efikasnost primarne poljoprivredne proizvodnje je predmet konstantnih analiza, kako energetskih tako i ekonomskih i ekoloških. Bez obzira na tehničko unapređenje proizvodnje, $i$ dalje se traže proizvodni i tehnološko-tehnički sistemi koji će dati energetski efikasniju i ekološki održivu primarnu biljnu proizvodnju.

U radu je prikazan bilans potrošnje energije u proizvodnji ratarskih kultura i skrenuta je pažnja na mineralna đubriva. Potrošnja energije je praćena u proizvodnji pšenice, kukuruza, semenskog suncokreta, šećerne repe i soje, tokom tri proizvodne sezone. Data je analiza potrošnje energije kroz sve postupke manipulacije mineralnim đubrivima do i od imanja pa do same aplikacije na parceli. Analizirana je zavisnost ukupnih energetskih inputa i prinosa i korelacija utroška mineralnog đubriva i outputa.

Rezultati istraživanja pokazuju da mineralna đubriva, u energeskom bilansu ratarske proizvodnje, učestvuju sa 40,52\% (semenski suncokret) pa do 55,19\% (kukuruz). Najintenzivniji utrošak energije po jedinici površine zabeležen je u proizvodnji šećerne repe, 27848,9 MJ ha ${ }^{-1}$ dok je najmanje energije utrošeno kod soje, 11371,28 MJ ha ${ }^{-1}$. Proizvodnja šećerne repe je energetski najproduktivnija (1,58 $\mathrm{kg} \mathrm{MJ^{1 }}$ ). Najviše energije, kod manipulacije $i$ aplikacije đubriva, je utrošeno u proizvodnji pšenice, 14,54 MJ ha ${ }^{-1}$, a najmanje u proizvodnji soje, 3,23 $\mathrm{MJ} \mathrm{ha}^{-1}$. Statistička analiza je pokazala da postoji korelacija između energije utrošene preko đubriva i samog prinosa ratarskih kultura. Funcionalna veza između inputa putem đubriva i prinosa je jaka u svim slučajevima osim kod soje. Regresione jednačine pokazuju pozitivnu zavisnost između prinosa i uložene energije preko đubriva, osim u slučaju pšenice i semenskog kukuruza.

Ključne reči: mineralna đubriva, ratarska proizvodnja, energetski bilnas, energetska efikasnost.

\section{INTRODUCTION}

Ecological, economic and energy efficiency are the principal requirements of sustainable agriculture. The energy consumption in agriculture has increased in recent years due to booming population growth, limited supply of arable land and the need for higher living standards (Erdal et al., 2007). The share of energy consumed in agriculture is considered very large, ranging up to 5 $\%$ of the total energy consumption in some countries (Lupu and Lupu, 2000; Malnou et al., 2008).

Fertilizing is one of the cultural practices that greatly affect crop production (60-70 \%). Modern agricultural production cannot be imagined without the use of fertilizers, particularly in terms of the better utilization of plant biological yields (Domupa et al., 2004; Sãulescu et al., 2005; Zengin et al., 2009; Dawson and Hilton, 2011; Cociu, 2012; Šeremešić et al., 2019). Without fertilizing, crop yields would be significantly reduced despite other cultural practices such as tillage, crop protection, irrigation, etc. The energy consumption of fertilizers claims a major share of the total energy consumption in crop production, approximating to $50 \%$ (Canakci et al., 2005).

In agricultural practice, the nutritive value of fertilizers is assessed according to their impact on the increase in crop yields and the improvement of yield quality (Lupu and Lupu, 2000; Malnou et al., 2008). However, the energy flow in the production and application of fertilizers has been receiving increased attention, particularly the transport, storage and handling of fertilizers.

The objective of this study was to estimate the total amount of input-output energy in maize, sunflower, wheat, sugar beet and soybean production with an emphasis on the energy consumption and efficiency of fertilizer application. 


\section{MATERIAL AND METHOD}

The energy consumption in crop production is defined as the energy used for the production of crops until they leave the field (Safa et al, 2011). The energy inputs estimated in this research are those allocated to farm production systems prior to storage and post-harvest activities. The experimental data were collected during the course of three-year field trials (2009 - 20012) conducted on the property of PKB Corporation "7 July" in Jakovo (Vojvodina, Serbia).

The method used for the energy efficiency analysis in the present study (Ortiz-Canavate and Hernanz, 1999) is based on the energy input analysis (namely direct and indirect energy inputs), the energy used for the production of a specific crop and the energy efficiency of such production. On the basis of sugar beet and wheat production outputs and the associated energy inputs, the specific energy input, the energy output-input ratio and the energy productivity were estimated as follows:

$$
\text { Energy input/kg of pro.(EI) }=\frac{\text { energy input for prod.[MJ/ha] }}{\text { output }[\mathrm{kg} / \mathrm{ha}]}
$$

Energy out/in ration $(\mathrm{ER})=\frac{\text { energy value of } \operatorname{prod} .[\mathrm{MJ} / \mathrm{ha}]}{\text { energy input for the } \operatorname{prod} .[\mathrm{MJ} / \mathrm{ha}]}$

$$
\text { Energy productivity }(\mathrm{EP})=\frac{\text { prod. }[\mathrm{kg} / \mathrm{ha}]}{\text { energy input for the prod. }[\mathrm{MJ} / \mathrm{ha}]}
$$

The regression and correlation analysis was used to determine the energy input/yield relation, the energy input for the fertilizer/yield relation and the energy input/output relation.

\section{RESULTS AND DISCUSSION}

The energy inputs for maize, sunflower, wheat, sugar beet and soybean production are presented in Table 1 . The largest amount of energy was used in the sugar beet production considered (27.84 GJ/ha), whereas the lowest energy consumption per unit area was calculated in the soybean production considered (11.37 GJ/ha) (Fig. 1). Gulistan et al. (2007) reported that the energy needed for sugar beet production in Turkey amounted to $39.69 \mathrm{GJ} / \mathrm{ha}$, with fertilizers accounting for $49.33 \%$. Asgharipour et al. (2012) found that the energy consumption in sugar beet production in Iran amounted to 42.23 GJ/ha, with fertilizers accounting for $29 \%$. Ramedani et al. (2011) established that a total of $18.03 \mathrm{GJ} / \mathrm{ha}$ are required for the soybean production in Iran, with diesel fuel, fertilizers and irrigation accounting for $66.67 \%, 14.32 \%$ and $6.18 \%$ of the total energy consumption, respectively. Abbas and Majid (2012) reported similar results for Iran, i.e. an energy consumption of $29.90 \mathrm{GJ} / \mathrm{ha}$ with diesel fuel and fertilizers accounting for $67.47 \%$ and $9.5 \%$, respectively.

The energy consumption in the maize production considered was $19.38 \mathrm{GJ} / \mathrm{ha}$. Memon et al. (2012) reported an energy input of $12.69 \mathrm{GJ} / \mathrm{ha}$ for the maize production in Pakistan, most of which was the energy allocated to fertilizers (10.65 GJ/ha). They also reported a high energy output of $83.11 \mathrm{GJ} / \mathrm{ha}$, which contributed to the better overall energy efficiency. Abdi et al. (2012) recorded an energy consumption of $26.92 \mathrm{GJ} / \mathrm{ha}$, whereas Lorzadeh et al. (2011) reported an energy input of $29.31 \mathrm{GJ} / \mathrm{ha}$ with fertilizers accounting for $48.25 \%$.

The energy consumption in the sunflower production considered was $15.21 \mathrm{GJ} / \mathrm{ha}$. Mousavi et al. (2012) reported an energy input of $9.6 \mathrm{GJ} / \mathrm{ha}$ for the sunflower production in Iran, with a fertilizer share of 21.7 \%. Davoodi and Haushhyar (2009) also reported an energy consumption of $22.95 \mathrm{GJ} / \mathrm{ha}$ for the production conditions of Iran, with fertilizers accounting for

Table 1. Energy input and output in maize, sunflower, wheat,

\begin{tabular}{|c|c|c|c|c|c|}
\hline \multirow[t]{2}{*}{ Input } & \multicolumn{5}{|c|}{ Energy input in crop production $\left(\mathrm{MJ} \mathrm{ha}^{-1}\right)$} \\
\hline & Maize & Sunflower & Wheat & Sugar beet & Soybean \\
\hline Diesel fuel (l) & $3,998.14$ & $3,899.68$ & $4,176.59$ & $7,564.83$ & $4,144.9$ \\
\hline Kerosene (l) & & 189.62 & & 200.13 & \\
\hline Labor (h) & 11.44 & 27.87 & 15.70 & 19.28 & 11.52 \\
\hline Tractor (h) & 492.36 & 1028.7 & 664.01 & 833.83 & 491.44 \\
\hline Combine (h) & 41.48 & 36.22 & 42.36 & 63.39 & 42.36 \\
\hline Transport (h) & 35.17 & 52.35 & 50.66 & 112.64 & 32.98 \\
\hline Machinery (h) & 312.25 & 620.94 & 381.42 & 380.59 & 297.62 \\
\hline Manure (t) & $2,890.56$ & & & & \\
\hline Nitrogen $(\mathrm{kg})$ & $9,744.54$ & $5,746.59$ & $11,599.50$ & $11,899.20$ & 4406.1 \\
\hline $\begin{array}{c}\text { Phosphorus } \\
\text { (kg) }\end{array}$ & 347.49 & 301.0 & 480.67 & 778.74 & 311.79 \\
\hline $\begin{array}{c}\text { Potassium } \\
(\mathrm{kg})\end{array}$ & 48.5 & 215.6 & 18.89 & 997.26 & 85.19 \\
\hline $\begin{array}{c}\text { Insecticides } \\
(\mathrm{kg})\end{array}$ & & 301.58 & 153.11 & 689.85 & 101.54 \\
\hline $\begin{array}{c}\text { Fungicides } \\
(\mathrm{kg})\end{array}$ & & & 142.56 & 212.77 & \\
\hline $\begin{array}{c}\text { Herbicides } \\
(\mathrm{kg})\end{array}$ & $1,236.81$ & $2,620.38$ & 154.31 & 3,330.41 & $1,105.91$ \\
\hline Water $\left(\mathrm{m}^{3}\right)$ & 0.68 & 98.06 & 0.07 & 1.74 & 1.16 \\
\hline Seeds (kg) & 219.08 & 67.47 & $4,459.10$ & 835.17 & 338.8 \\
\hline $\begin{array}{c}\text { Total energy } \\
\text { input } \\
\left(\mathrm{MJ} \mathrm{ha}^{-1}\right)\end{array}$ & $19,378.5$ & $15,206.06$ & 22,339.00 & $27,848.92$ & $11,371.28$ \\
\hline $\begin{array}{l}\text { Output } \\
\left(\mathrm{MJ} \mathrm{ha}^{-1}\right)\end{array}$ & $53,207.04$ & 33,963.42 & $63,499.60$ & $809,044.0$ & $79,948.99$ \\
\hline
\end{tabular}
sugar beet and soybean production

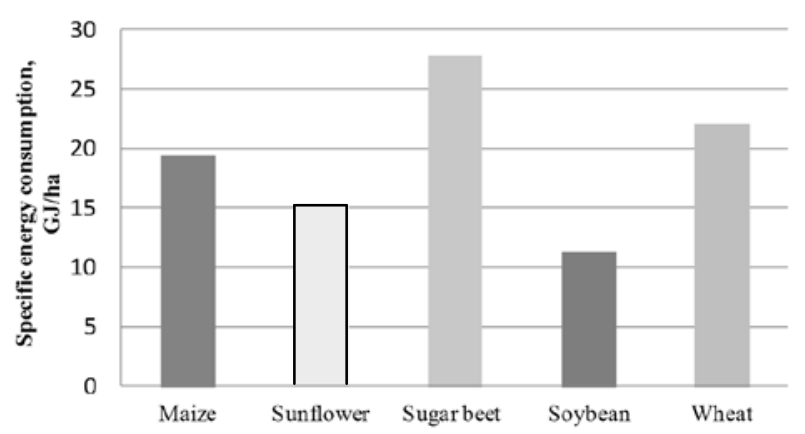

Fig. 1 Specific energy consumption in crop production

$26.64 \%$. The results similar to those recorded in Serbia were reported in Turkey, i.e. an energy consumption of $18.93 \mathrm{GJ} / \mathrm{ha}$ with a fertilizer share of $51.28 \%$ (Uzunoz et al).

The results obtained indicate that the energy needed for wheat production in Serbia is $22.34 \mathrm{GJ} / \mathrm{ha}$. Acording to Ramah and Baalij (2011), an energy input of $7.48 \mathrm{GJ} / \mathrm{ha}$ is required for the wheat production in Morocco, with a fertilizer share of 40.50 $\%$. Shanin et al. (2008) stated that, under the production conditions of Iran, an energy input of $38.36 \mathrm{GJ} / \mathrm{ha}$ in needed for wheat production, with fertilizers accounting for $38.45 \%$. Kardoni et al. (2013) reported an energy input $35.61 \mathrm{GJ} / \mathrm{ha}$ and a fertilizer share of $47.30 \%$ for the wheat production in Iran. 
These energy inputs were higher compared to the results obtained in the present study due to irrigation.

As expected, the highest energy output was calculated for sugar beet production (809.04 GJ/ha), whereas the lowest energy output was calculated for sunflower production (33.96 GJ/ha).

On the basis of the correlation between energy inputs and crop yields (Tab. 2), positive regression coefficients were found in soybean and sugar beet production. Therefore, crop yield increases can be expected provided energy inputs are increased by $1 \mathrm{GJ} / \mathrm{ha}$ (in cases of soybean and sugar beet such increments would amount to $2.238 \mathrm{t} / \mathrm{ha}$ and $2.953 \mathrm{t} / \mathrm{ha}$, respectively). However, an increase in energy consumption leads to lower yields in all other crops considered. A high correlation was found in all the crops considered, with the exception of maize and sunflower.

Table 2. Linear regression equation for the energy inputs and yields in crops production

\begin{tabular}{||c|c|}
\hline \hline Crop & Regression equation \\
\hline Wheat & $\hat{y}_{\mathrm{i}}=8.450-0.182 \mathrm{x}_{\mathrm{i}}$ \\
\hline Maize & $\hat{y}_{i}=32.105-1.139 x_{i}$ \\
\hline Soybean & $\hat{y}_{i}=-22.650+2.238 x_{i}$ \\
\hline Sunflower & $\hat{y}_{i}=1.844-0.031 x_{i}$ \\
\hline Sugar beet & $\hat{y}_{i}=-34.028+2.953 x_{i}$ \\
\hline
\end{tabular}

According to the energy input structure shown in Table 1, indirect energy inputs (namely energy inputs for fertilizers, labor, machinery, water, chemicals and seed) accounted for most of the energy used in crop production. As expected, fertilizers claimed the largest share of the total energy consumption, ranging from $41 \%$ in sunflower production up to $55.19 \%$ in maize production (Fig. 2), followed by fuel and seeding material in wheat production.

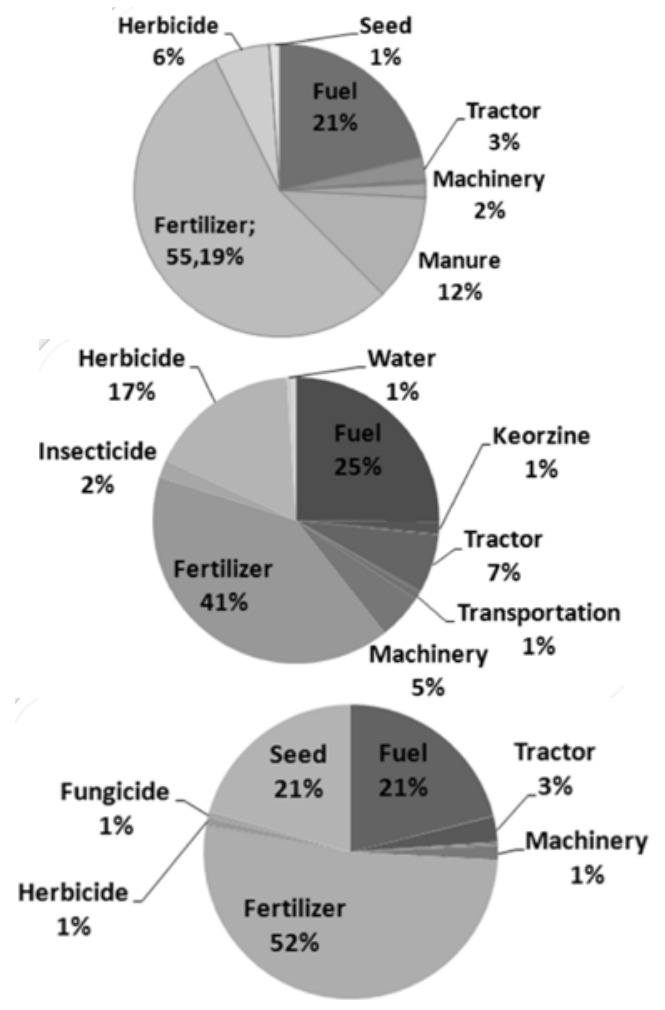

Fig. 2 Energy input share of the total energy consumption in maize, sunflower and wheat production

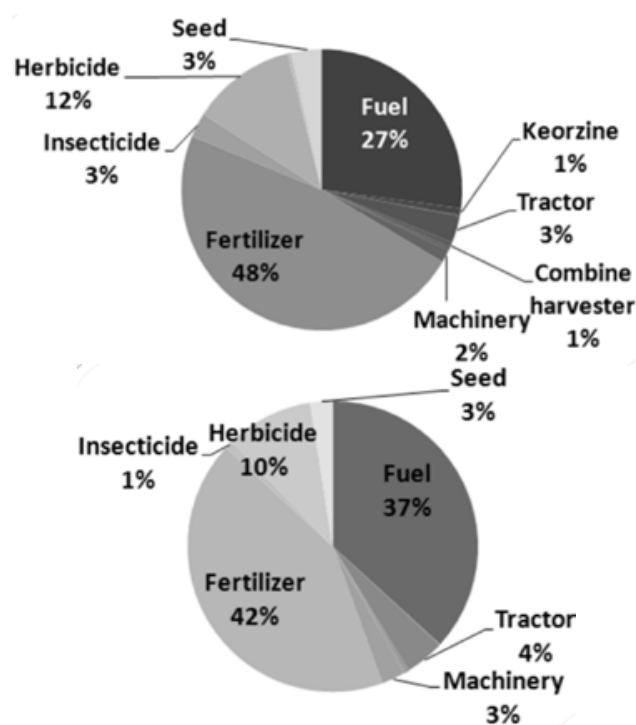

Fig. 3 Energy input share of the total energy consumption in sugar beet and soybean production

A strong functional correlation was found between the energy inputs for fertilizers and yields in all the crops considered, with the exception of soybeans. Linear regression equations (Tab. 3) indicate a positive correlation between the energy inputs for fertilizers and yields in maize, soybean and sugar beet production. As seen in Table 3, an increase of $1 \mathrm{GJ} / \mathrm{ha}$ in fertilizer energy inputs results in the following maize, soybean and sugar beet yield increments: $3.815 \mathrm{t} / \mathrm{ha}$ in maize production, $0.26 \mathrm{t} / \mathrm{ha}$ in soybean production and $3.88 \mathrm{t} / \mathrm{ha}$ in sugar beet production. In the case of sunflower production, the results obtained show that, at some point, yields were decreasing with the more intensive use of fertilizers. Therefore, the optimal plant nutrition must be set and followed because increased fertilizer application will not lead to the yield increment in sunflower production.

Table 3 Linear regression equations

\begin{tabular}{||c|c|c||}
\hline \hline & $\begin{array}{c}\text { Fertilizer vs. yield } \\
\text { energy }\end{array}$ & $\begin{array}{c}\text { Energy input vs. energy } \\
\text { output }\end{array}$ \\
\hline Maize & $\hat{y}_{i}=-28.560+3.815 x_{i}$ & $\hat{y}_{i}=322.184-10.581 x_{i}$ \\
\hline Sunflower & $\hat{y}_{i}=10.838-1.503 x_{i}$ & $\hat{y}_{i}=46.298-0.795 x_{i}$ \\
\hline Wheat & $\hat{y}_{i}=6.489-0.165 x_{i}$ & $\hat{y}_{i}=161.382-3.588 x_{i}$ \\
\hline Sugar beet & $\hat{y}_{i}=-5.009+3.883 x_{i}$ & $\hat{y}_{i}=-571.781+49.616 x_{i}$ \\
\hline Soybean & $\hat{y}_{i}=1.119+0.260 x_{i}$ & $\hat{y}_{i}=-564.298+57.711 x_{i}$ \\
\hline
\end{tabular}

The results obtained also indicate that there is a functional correlation between the energy inputs and outputs in crop production. Linear regression equations (Tab. 3) show that there is a positive correlation between the energy inputs and outputs only in sugar beet and soybean production, indicating that only in these cases higher energy inputs lead to higher energy outputs. In all other crops considered, special care must be taken in balancing energy inputs. The specific energy input shows how much energy is spent for the yield produced. The results obtained indicate that the highest specific energy input relative to yield was recorded in sunflower production $(11.58 \mathrm{MJ} / \mathrm{kg}$ ), whereas the lowest specific energy input relative to yield was observed in sugar beet production (0.93 MJ/kg) (Fig. 4). The energy ratio was determined on the basis of energy inputs and outputs (Ortiz-Canavate and Hernanz 1999). If the energy ratio value is more than one, the system is generating energy. 


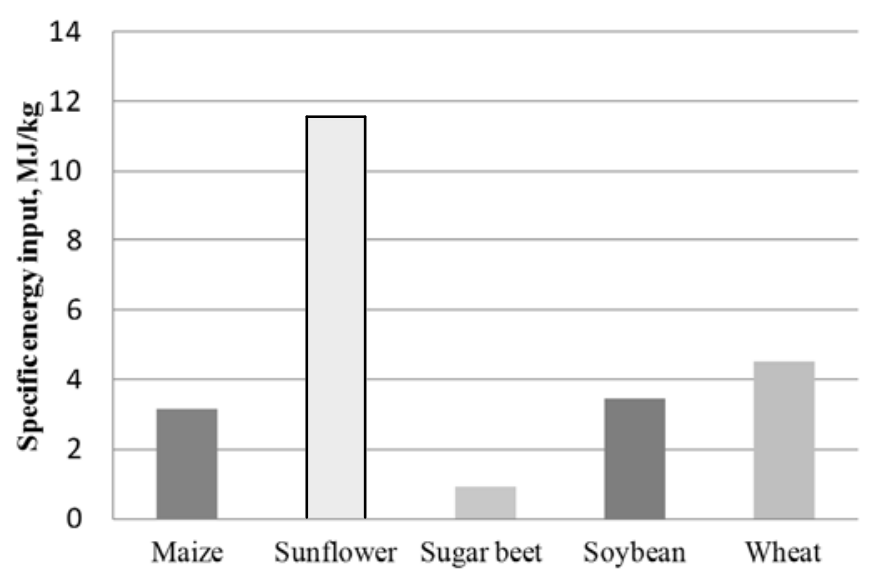

Fig. 4 Specific energy input in crop production

However, if the energy ratio is less than one, the system is losing energy (Confroti and Gianpietro 1997). The results obtained show that the production of all the crops considered is generating energy (Fig. 5).

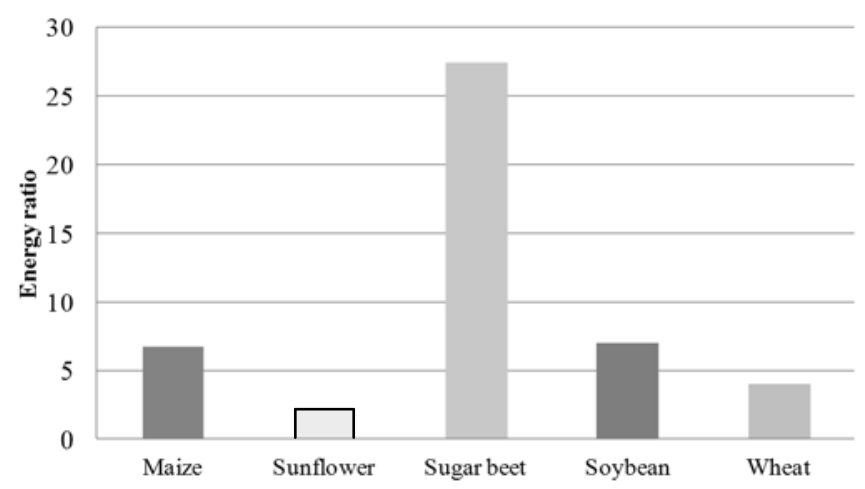

Fig. 5 Energy ratio in crop production

The lowest energy ratio was recorded in the sunflower production considered (2.25), whereas the highest energy ratio was observed in the sugar beet production considered (26.45).

Energy productivity (EP) is the measure of the amount of products obtained per unit of input energy. EP is specific for each agricultural product, location, and time (Ortiz-Canavate and Hernanz 1999). It can serve as an evaluator of how efficiently energy is utilized in different production systems that yield a particular product. The results obtained in this study show that sugar beet production is highly energy productive with an EP of $1.58 \mathrm{~kg} / \mathrm{MJ}$ (Fig. 6). However, sunflower production was found to be the least energy productive of all the crops considered $(0.09 \mathrm{~kg} / \mathrm{MJ})$.

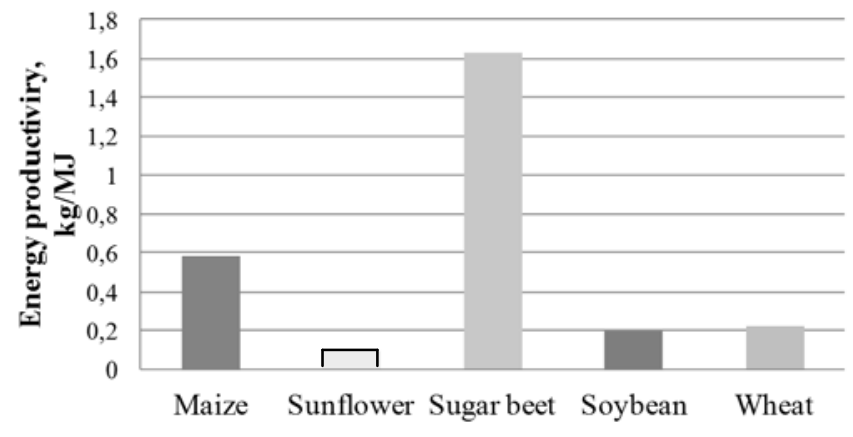

Fig. 6 Energy productivity in crop production
To improve the EP in crop production, it is possible either to reduce the energy sequestered in the inputs or to increase the yield of products. The quantity, quality and application uniformity of fertilizers can be utilized to improve the energy productivity in crop production as fertilizers participate in the total energy input with more than $40 \%$ (Gavrilović et al., 2018). Table 4 shows how much energy is used for the handling and application of fertilizers, including fertilizer transport (trailer loading, transport and spreader loading), fertilizer application (fertilizer, tractor and spreader) and human labor.

Table 4. Energy input in fertilizer handling and application

\begin{tabular}{|c|c|c|c|c|}
\hline \hline Crop & $\begin{array}{c}\text { Transpo. } \\
\text { MJ/ha }\end{array}$ & $\begin{array}{c}\text { Application, } \\
\text { MJ/ha }\end{array}$ & $\begin{array}{c}\text { Human } \\
\text { labor, } \\
\text { MJ/ha }\end{array}$ & $\begin{array}{c}\text { Total, } \\
\text { MJ/ha }\end{array}$ \\
\hline Wheat & 14.54 & $12,154.33$ & 1.99 & $12,170.86$ \\
\hline Maize & 8.84 & $10,175.67$ & 1.20 & $10,185.71$ \\
\hline Sugar beet & 12.45 & $13,732.66$ & 1.70 & $13,746.81$ \\
\hline Soybean & 3.23 & $4,832.00$ & 0.55 & $4,835.78$ \\
\hline Sunflower & 7.84 & $6,324.67$ & 1.15 & $6,333.66$ \\
\hline
\end{tabular}

As expected, fertilizer application was found to be the most energy-consuming. Therefore, special attention should be devoted to fertilizer application to assure more energy productive and efficient crop production. As seen in Table 4, sugar beets are the most energy-consuming corps relative to fertilizer application, followed by wheat and maize.

\section{CONCLUSION}

Ecological, economic and energy efficiency are the principal requirements of sustainable agriculture. The energy consumption in agriculture has increased in recent years due to increased food demands and limited supplies of arable land. Fertilizers claim the largest share of the total energy consumption in crop production (exceeding $50 \%$ ). Higher energy inputs are introduced to generate higher yields. The objective of this paper was to examine the energy consumption in the production of predominant crops in Serbia.

The largest amount of energy was used in the sugar beet production considered (27.84 GJ/ha), whereas the lowest energy consumption per unit area was calculated in the soybean production considered (11.37 GJ/ha). As expected, the highest energy output was calculated for sugar beet production (809.04 $\mathrm{GJ} / \mathrm{ha}$ ), whereas the lowest energy output was calculated for sunflower production (33.96 GJ/ha). Fertilizers claimed the largest share of the total energy consumption in the crop production considered, ranging from $41 \%$ in sunflower production up to $55.19 \%$ in maize production. Moreover, a positive correlation was found between the fertilizers applied and the yields produced in maize, soybean and sugar beet production. The quantity, quality and application uniformity of fertilizers can be utilized to improve the energy productivity in crop production as fertilizers participate in the total energy input with more than $40 \%$.

Fertilizer application was found to be the most energyconsuming. Therefore, special attention should be devoted to fertilizer application in order to assure more energy productive and efficient crop production.

ACKNOWLEDGEMENTS: The authors wish to thank the Ministry of Education, Science and Technological Development of the Republic of Serbia for financing Project TR 31051. 


\section{REFERENCES}

Abbas, D., Majid, A. (2012). Input-output and economic analysis of soybean production in the main cultivation areas in Iran. African Journal of Agricultural Research 7 (35), 48944899.

Abdi, R., Hematian, A., Mobtaker, H.G., Shahamat, E.Z. (2012). Senzitivity analysis of energy input for maize production system in Kermanshah province of Iran. Animal and Environmental Sciences 2 (3), 84-91.

Asgharipour, M., Mondani, F., Riahinia, S. (2012). Energy use efficiency and economic analysis of sugar beet production system in Iran: A case study in Khorasan Razavi province. Energy, 44, 1078-1084.

Canakci, M., Topakci, M., Akinci, I., Ozmerzi, A. (2005). Energy use pattern of some field crops and vegetable production: Case study for Antalya Region, Turkey. Energy Conversion and Management, 46, 655-666.

Conforti, P., Giampietro, M. (1997). Fossil energy use in agriculture: an international comparison. Agricultural Ecosystems and Environment, 65(3), 231-243.

Davoodi, M.J.S., Houshyar, E. (2009). Energy Consumption of Canola and Sunflower Production in Iran. American-Eurasian Journal of Agriculture \& Environment Science 6 (4), 381-384.

Dawson, C.J., Hilton, J. (2011). Fertilizer availability in a resource-limited world: production and recycling of nitrogen and phosphorus. Food Policy, 36, S14-S22.

Erdal, G., Esengün, K., Erdal, H., Gündüz, O. (2007). Energy use and economical analysis of sugar beet production in Tokat province of Turkey. Energy, 1 (32), 35-41.

Gülistan, E., Esengün, K., Erdal, H., Gündüz, O. (2007). Energy use and economical analysis of sugar beet production in Tokat province of Turkey. Energy 32, 35-41.

Gavrilović Marija, Dimitrijević Aleksandra, Radojičin, M., Mileusnić, Z., Miodragović, R. (2018). Uticaj tehnološkotehničkog sistema aplikacije mineralnih đubriva na njihove fizičko-mehaničke osobine. Journal on Processing and Energy in Agriculture, 22 (4), 180-183

Kardoni, F., Parande, S., Jassemi, K., Karami, S. (2013). Energy Input-output Relationship and Economical Analysis of Wheat Production in Khuzestan Province of Iran. International Journal of Agronomy and Plant Production, 4 (9), 2187-2193.

Mousavi Avval, S.H., Rafiee, S., Keyhani, A. (2012). Energy efficiency analysis in agricultural productions: parametric and non-parametric approaches. Energy Efficiency - A Bridge to Low Carbon Economy, 135-158.
Lorzadeh, Sh., Mahdavidamghani, A., Enayatgholizadeh, M.R., Yousefi, M. (2011). Agrochemical Input Application and Energy Use Efficiency of Maize Production Systems in Dezful, Iran. Middle-East Journal of Scientific Research 9 (2), 153-156.

Lupu, C., Lupu, G. (2000). Influence of Fertilization and Bacterization on Soybean Production and Biological Peculiarities. Romanian Agricultural Research, 13-14, 67-79.

Malnou, C.S., Jaggard, K.W., Sparkes, D.L. (2008). Nitrogen fertilizer and the efficiency of the sugar beet crop in late summer. European Journal of Agronomy, 2008, 28(1), 47-56.

Memon, Sh. Q., Mirjat, M.S., Mughal, A. Q., Amjad, N. (2012). Eevaluationof inputs and outputs energy for maiye grain yield. Sarhad Journal of Agriculture, 28 (3), 387-393.

Ortiz-Cañavate, J., Hernanz, J.L. (1999). Energy analysis. In CIGR handbook of agricultural engineering, American Society of Agricultural Engineers, Michigan, USA, Volume 3, 13-42.

Ramah, M., Baali, E.H. (2012). Energy balance of wheat and barley under Moroccan conditions. International Conference Of Agricultural Engineering CIGR-AgEng2012 Papers Book, C-0822.

Ramedani, Z., Rafiee, S., Heidari, M.D. (2011). An investigation on energy consumption and sensitivity analysis of soybean production farm. Energy 36 (11), 6340-6344.

Safa, M., Samarasinghe, S., Mohssen, M. (2011). A field study of energy consumption in wheat production in Canterbury, New Zealand. Energy Conversion and Management, 7 (52), 2526-2532.

Shahin, S., Jafari, A., Mobli, H., Rafiee, S., Karimi, M. (2008). Effect of Farm Size on Energy Ratio for Wheat Production: A Case Study from Ardabil Province of Iran. American-Eurasian Journal of Agriculture \& Environment Science, 3 (4), 604-608.

Šeremešić, S., Manojlović Maja, Vojnov, B., Babec, Brankica, Koren, Anamarija, Mirjačić, Tamara, Sikora, V. (2019). Comparative study of growing winter small grain cereals in organic and conventional production systems. Journal on Processing and Energy in Agriculture 23 (4), 176-179

Uzunoz, M., Akcay, Y., Esengun, K. (2008). Energy Inputoutput Analysis of Sunflower Seed (Helianthus annuus L.) Oil in Turkey. Energy Sources, Part B: Economics, Planning, and Policy, 3 (3), 215-223.

Zengin, M., Gö̈kmeni, F., Yazici, M.A., Gezgin, S. (2009). Effects of potassium, magnesium, and sulphur containing fertilizers on yield and quality of sugar beets (Beta vulgaris L.). Turkish Journal of Agriculture and Forestry, 33, 495-502.

Received: 06.03.2020.

Accepted: 09.04.2020. 